\title{
Review
}

\section{Aging in Central America and the Caribbean}

Reseña

Envejecimiento en Centroamérica y el Caribe

Resenha

Envelhecimento na América Central e no Caribe

Roberth Steven Gutiérrez Murillo ${ }^{1}$

Aging in Central America and the Caribbean (Envejecimiento en Centroamérica y el Caribe) is the most recent book published by Centro de Investigaciones sobre América Latina y el Caribe - CIALC, of the Universidad Autónoma de México, organized by Aída DíazTendero Bollain and published in 2018, which addresses the issue of human aging in the individual and collective spheres (1). The material is part of the collection Politics, Economy and Society in Latin America and the Caribbean, which focuses on several topics of current interest to region's countries. In general, the book deals with an interdisciplinary debate on the problematization, the disciplinary vision and the critical analysis of three divergent but complementary landmarks: sociodemography, political economy and human rights, addressing the social phenomenon of population aging in Central American and Caribbean countries, in the contemporary of the XXI Century.

Bollain obtained a Ph.D. in Latin American Studies at the Universidad Complutense de Madrid. She then conducted a Post-doc at El Colegio de la Frontera Norte de México, researching on sociology of ageing and the human rights of older people in Latin America and the Caribbean. Currently, she is a full-time researcher at CIALC and a permanent professor in the Master of Social Work. Among her main contributions to the gerontological area, it should be noted: The political economy theory of aging. A new approach to social gerontology in Mexico, published in 2012 and Gender and Old-Age, coordinated in collaboration and published in 2017 (2).

\footnotetext{
1 Mestrando, Programa de Pós-graduação em Gerontologia, Universidad Europea del Atlántico (UNEATLANTICO), Cantábria, Santander, Espanha; residente, Programa de Residência Multiprofissional em Saúde da Família, Universidade Federal da Integração Latino-americana (UNILA), Foz do Iguaçu, Paraná, Brasil; sanitarista. https://orcid.org/0000-00032304-3241. E-mail: stevengumu@gmail.com
} 
In the first chapter, entitled Fom sociodemography (Desde la sociodemografía), Bollain presents the determinants of demographic transmission in Central America and the Caribbean, resuming the discussion of demographic vulnerabilities and the interaction between the population and human development binomial. She points out that the first demographic transmission and vulnerability in these territories have been divided into three socio-temporal passages, namely: 1) agrarian and traditional societies with high fertility and mortality rates; 2) the population-development approach, which defended, on the one hand, the Neomalthusian vision and which, on the other hand, found that modernization of societies automatically generates a reduction in population growth and; 3 ) the concern for social structure and the issue of social inequalities in different strata and age groups.

The current scenario of population aging in the region points to $12.3 \%$ of elderly people in the Caribbean and $9 \%$ in Central America. Moreover, the rural to urban transition in those societies has exposed the health and social challenges in the aging population, causing, in turn, a positivist positioning in the State's structures (health and welfare systems). Thus, states acknowledge that many and complex are the challenges faced by the aged population segment. Therefrom, specific rights should be granted to this socially vulnerable group, in order to respect and promote integrality and autonomy, still in these life contexts. In fact, the insertion of humanizing and democratizing mechanisms, about the social and health care provided to aging users, has also been a relevant aspect in the state actions of Central American and Caribbean countries.

From the political economy (Desde la economía política) is the title given to the second chapter of the work. It suggests a dialogue on the concept of economic solidarity for the elderly covering the angles of intergeneration; interparity, interclass and intracorporativism; universality and social solidarity. In this concept, solidarity would be the principle behind the systems of assistance and social security, the articulators of social policy. Therefore, economic solidarity consists in the ascertainable fact of the need to exercise solidarity among members of a society on condition of offering help, and in members of that society of receiving it.

The social phenomenon of population aging evidences the growth, development and complexity of society, producing, concomitantly, the effects of social stratification and differentiation, seen through the prism of social inequality and inequity with important negative influence of the age question. In this way, aged citizens would go through greater social difficulties, directly affecting the morbidity and mortality rates expressed in old-age. 
Concluding the chapter, there is a discussion about the approach of the political economy of aging in the dimensions of class; gender; race/ethnicity; geographic location; corporativism and minority groups. Both mentioned characteristics are interdependent, and the health and social care systems must have the technical capacities for their multidimensional and interdisciplinary approach. In truth, like a kind scenario has been repeatedly discussed by regional and international organizations, with their north in fully understanding the social phenomenon of aging. Citing, for example, the Economic Commission for Latin American and the Caribbean (ECLAC) for more than twenty years has been calling on the multilateral impasses that population aging will bring in the Latin American societies, hence the importance of intensifying the collective efforts to formulate possible approaches (3).

The third chapter - From the Human Rights (Desde los Derechos Humanos) - evokes a historical review of the international human rights framework for the elderly. In the space, an explanation about universal instruments and regional instruments of Human Rights is given. In the second case, a comparison is made at the European, African and Latin American levels. The chapter is also complemented by observing the countries' social welfare systems, precisely by highlighting the main reforms (scopes and effects) in the legal and health system that concern the aging population segment. Panama (44.97\%) and Costa Rica (40.99\%) stand out with higher coverage rates for retirement among the population 65 years of age and older, respectively. From this same apprehensive angle, it is possible to perceive the adversity faced by the region in its inability to reach the regional average coverage (21.38\%), most notably in Honduras, where this figure reaches only $5.11 \%$.

According to the author, this challenge has been tensioned by the strong wave of privatization of health and social assistance services, which has unleashed the interruption of ties of intergenerational solidarity and made it challenging to continue economic solidarity for older adults. This consequence, however, is not unique to the countries that are accompanied in this work, as is also perceivable in most countries of the world. On the other hand, arguments aimed at understanding the function of civil, political and social rights, in the broad sense, are based on interesting notes in the last part of this chapter. For example, the validation of legal principles in the positivist aspect of the law is analyzed, with a noteworthy touch of family law, discussing the indissolubility and interdependence with other areas, such as: culture, environment and economy, and State's accountability for the enforceability of these fundamental rights. 
Hitherto, the promotion of legal instruments for the prioritization of social guarantees for older Central American and Caribbean citizens, in addition to the promotion of constitutional rights already acknowledged, do not figure current issues in these territories. That has been the case since 1969, by dint of the adhesion to the Pact of San José, Costa Rica (The American Convention on Human Rights), through which such nations committed "to respect the rights and freedoms recognized therein and to guarantee their free and full exercise to any person who is subject to its jurisdiction, without any discrimination (...) or any other social condition" (4).

Following that line of thought, in 2010, the ECLAC published an e-book entitled Ageing, Human Rights and Public Policies, sharing a critical-analytical debate on the First and Second Regional Intergovernmental Conference on Ageing in Latin America (5). Likewise, it should be noted that the Third Regional Intergovernmental Conference on Ageing in Latin America was held in San José, Costa Rica, in 2012, aimed at reviewing achievements in the implementation of international commitments made by ECLAC member countries in the Brasilia's Declaration, adopted in 2007 (6).

All three conferences brought relevant insights to address the matter of fundamental rights in old-age, i.e., decent housing, employment, education, social security, health, food, leisure and citizen participation $(5,6)$. Yet, one of their most significant results was the San José Charter on the Rights of Older Persons in Latin America and the Caribbean, as also considered by Bollain (7).

Addressing the scope of assistance to the health demands of older adults, member countries have agreed to promote the universalization of the right to health; to design and implement policies for comprehensive preventive health care, with a gerontological and interdisciplinary approach, particularly through primary care and including rehabilitation services; to facilitate preferential access to drugs, equipment, technical aids and comprehensive rehabilitation services to promote the independence of older people, taking into account the possibilities of the different countries; to promote the development and access to palliative care, to ensure a dignified and painless death to individuals with terminal diseases; among others (7).

Diving deeper into the right to health, Bollain argues that "it includes timely, acceptable and affordable access to health care services of sufficient quality" (1). Whereas, in Central American and Caribbean countries, "the validation of the right to health must lead, in particular, to conventional or allopathic medicine, but also to alternative and complementary 
assistance paradigms", since they permeate intrinsic characteristics of native and modern peoples, more easily visible in older adults (1). However, it is worth remembering that "the situation in the region as regards access to these services is mixed and not well understood. Countries' situations differ by their development level, and access also varies within countries" (5).

In the last chapter of the book, entitled Countries' profile (Perfil por país), the sociodemographic characteristics of each country are described, thus allowing to draw a regional profile of population aging. In this way, Costa Rica, Cuba, Panama and El Salvador present an advanced population aging index; the Dominican Republic fits in the moderate-Advanced axis; and Haiti, Honduras and Nicaragua experience aging in a moderate way. Such trends seem to follow the urbanization index in these countries, that is, more urbanized countries present lower fecundity coefficient, therefore, higher ratio of population aging. Regarding the main causes of mortality in elderly people, there are: cardiovascular diseases; neoplasms and diseases of the respiratory system, being in line with the mortality profile in Latin America.

Older adults' participation in the formal labor market is also analyzed in the chapter, exposing favorable profiles in Costa Rica, Panama and Cuba. Contrary to what has been reported, in Haiti, El Salvador, Nicaragua, the Dominican Republic and Honduras, more complicated circumstances prevent an equal prosperity among their aged citizens. In view of this, the enigma of gender in the process of human aging is pondered. Women, who have a longer life expectancy, have, in turn, fewer barriers to access the labor market and schooling options and, as a result, no financial independence. Thusly, the contributions in this book go beyond statistical and/or epidemiological readings of aging, since it portrays palpitating concerns among Central American and Caribbean inhabitants, who age in an accelerated manner and in unequal contexts.

Without room for hesitation, the book integrates a careful gerontological tool for the multidimensional understanding of the various issues related to population aging in the Central American continental axis and in its Caribbean. Its scientific rigor can be seen as a practical example of interdisciplinarity, with total consonance between the areas questioned by the author, namely: sociology, economy, politics and health law. Therefore, the reading Aging in Central America and the Caribbean addresses, in short, one of the most important gerontological works produced so far in the region, as it invites readers to enter the broad world of social sciences oriented to the understanding of population aging, from the case of the countries of the Central American and Caribbean continental axis. 
As a theoretical-conceptual obstacle to the work, the unavailability of data in certain Caribbean countries can be mentioned, a situation also discerned by the author. Certainly, countries like Belize, Cuba and Jamaica reflect considerable scientific gaps in the technical literature that deals with the aging population. However, the tactical form in which the material offers through secondary data promulgated by international organizations, makes possible some projections for such territories, leaving no room for a vague understanding of the issues embraced. In fact, one of the remarkable recommendations for future research in the field of the Central American and Caribbean population aging is precisely the convenience of redoubling the index of gerontological production in the region, a fact that would allow understanding, in a more comprehensive way, the impacts of individual and collective aging in such nations.

Finally, the scientific quality of the book deserves to be highlighted, not only for the contributions made to gerontological science (which are extremely relevant), but also for its capacity of articulation with contemporary themes inherent to all developed societies and to those in the way of socioeconomic development, given the social inequality and the phenomenon of the feminization of old-age and the elaboration of social policies for the active approach of population aging in accelerated contexts. The basic contribution of the book is in its excellent capacity of interpretation of the divergent social and health realities of the countries observed, being its appreciation accessible and of paramount importance for all areas of knowledge, especially to those with the manifest interest of scrutinizing the social phenomenon of population aging.

\section{References}

1. Bollain TDA. Envejecimiento en Centroamérica y el Caribe. Ciudad de México, México: Centro de Investigaciones sobre América Latina y el Caribe - Universidad Autónoma de México; 2018. 248 p.

2. Cultura UNAM. Informaciones sobre el autor: Díaz Tendero Bollain, Aída. Universidad Autónoma de México; 2018.

3. Huenchuan S. Envejecimiento, personas mayores y Agenda 2030 par ael Desarrollo Sostenible: perspectiva regional y de derechos humanos. Comisión Económica para América Latina y el Caribe, Santiago de Chile; 2018. 259 p.

4. Organization of American States - OAS. American Convention on Human Rights "Pact of San Jose, Costa Rica". 1969. 
5. Huenchuan S. Ageing, Human Rights and Public Policies. Economic Commission for Latin American and the Caribbean (ECLAC). Santiago de Chile. 2010. 208 p.

6. United Nations, Economic Commission for Latin America and the Caribbean - ECLAC. Report of the Third Regional Intergovernmental Conference on Ageing in Latin America and the Caribbean: San José, 8-11 May 2012. United Nations; 2012. 49 p.

7. Comisión Económica para América Latina y el Caribe - CEPAL. Carta de San José sobre los derechos de las personas mayores en América Latina y el Caribe. 2012. 19 p.

Como citar este artigo

Murillo RSG. Aging in Central America and the Caribbean. Cadernos Ibero-Americanos de Direito Sanitário. 2021 jan./mar.;10(1):248-254.

https://doi.org/10.17566/ciads.v10i1.747 